\title{
PENGARUH TRANSPORTASI TERHADAP MUTU DAN HARGA IKAN DARI PELABUHAN PERIKANAN PANTAI LEMPASING KE DAERAH KONSUMEN
}

\author{
The Transportation Influence to The Quality and Price of Fish to Consumer Area from Coastal \\ Fishing Port of Lempasing
}

Oleh:

\author{
Andri Prastyo ${ }^{1 *}$, Ernani Lubis ${ }^{2}$, Fis Purwangka² \\ ${ }^{1}$ Mahasiswa Program Sarjana Departemen Pemanfaatan Sumberdaya Perikanan, FPIK, \\ Institut Pertanian Bogor \\ ${ }^{2}$ Staf Pengajar Departemen Pemanfaatan Sumberdaya Perikanan, FPIK, Institut Pertanian \\ Bogor \\ *Korespondensi: pras.andri09@gmail.com
}

\begin{abstract}
ABSTRAK
Ikan merupakan suatu komoditas bahan pangan yang mudah mengalami kerusakan (perishable food) karena adanya kandungan protein dan air yang cukup tinggi, oleh karena itu diperlukan suatu penanganan secara baik dan benar untuk mencegah agar penurunan mutu ikan tidak terjadi. Transportasi adalah suatu komponen penting yang digunakan untuk mempermudah dalam melaksanakan aktifitas sehari-hari seperti mendistribusikan ikan hasil tangkapan nelayan dari pelabuhan perikanan ke daerah konsumen. Tujuan penelitian ini adalah mendeskripsikan sarana transportasi yang digunakan dan penanganan ikan selama transportasi oleh pedagang untuk mendistribusikan ikan hasil tangkapan dari PPP Lempasing ke daerah konsumen, melakukan penilaian kembali mutu ikan di daerah konsumen setelah dilakukan transportasi dari PPP Lempasing ke daerah konsumen, menentukan faktor-faktor yang dapat mempengaruhi mutu ikan selama transportasi dari PPP Lempasing ke daerah konsumen, serta mendapatkan besaran harga ikan yang terbentuk di konsumen akhir dan faktor-faktor yang mempengaruhinya. Metode penelitian menggunakan metode studi kasus dan teknik pengambilan sampel dilakukan dengan menggunakan teknik purposive sampling. Hasil penelitian menunjukan bahwa, jenis transportasi yang digunakan oleh distributor untuk mendistribusikan ikan hasil tangkapan dari PPP Lempasing ke daerah konsumen di Kota Metro yaitu mobil pick-up dengan ukuran panjang 4,195 m, lebar 1,655 m, dan tinggi 1,850 m serta memiliki kapasitas angkut barang sebesar $820 \mathrm{~kg}$. Jenis wadah yang digunakan pada saat pendistribusian oleh distributor berupa wadah fiber dengan ukuran panjang $80 \mathrm{~cm}$, lebar 60 $\mathrm{cm}$, dan tinggi $70 \mathrm{~cm}$. Berdasarkan penilaian organoleptik terhadap kenampakan insang, mata, dan penekanan otot, terjadi penurunan nilai dari masing-masing kenampakan. Faktor-faktor yang mempengaruhi adanya penurunan mutu ikan yang terjadi adalah cara pemberian es dan kondisi keranjang yang digunakan. Besaran harga ikan yang terbentuk ketika sampai di tangan konsumen yaitu $\mathrm{Rp} 23.019,84 / \mathrm{kg}$ untuk ikan tongkol dan $\mathrm{Rp}$ 17.019,80/kg untuk ikan kuniran. Faktor-faktor yang mempengaruhi terhadap pembentukan harga ikan yaitu adanya biaya bahan baku pembelian ikan tongkol dan ikan kuniran, biaya tenaga kerja, dan biaya overhead.
\end{abstract}

Kata kunci: kondisi transportasi, mutu dan harga Ikan, Lempasing.

\section{ABSTRACT}

Fish is one of perishable food due to its high protein and water content, therefore it requires to be handled properly to prevent a declining of its quality. Transportation is an important component that is used to facilitate everyday activities including catch distribution from the fishing port to the 
consumer area. This research aims to describe the transportation and fish handling during transportation by traders to distribute the catch from Coastal Fishing Port of Lempasing to consumer area, re-measurement in the consumer area after distributing from Coastal Fishing Port of Lempasing to consumer area, determine the factors that can affect the quality of fish during transportation from Coastal Fishing Port of Lempasing to consumer area, and getting the fish price that are formed in the final consumer and the factors that influenced it. This research was conducted using case study and the sample was collected using purposive sampling. The result showed that the type of transportation used by the distributor to distribute the catches from Coastal Fishing Port of Lempasing to Metro City is pick-up car (length, $4.195 \mathrm{~m}$; width, $1.655 \mathrm{~m}$; height, $1.850 \mathrm{~m}$ ) and has $820 \mathrm{~kg}$ transport capacity. The type of container used at the time of distribution is fiber (length, $80 \mathrm{~cm}$; width, $60 \mathrm{~cm}$; and height, $70 \mathrm{~cm}$ ). Based on the organoleptic assessment of gill, eye, and muscle emphasis, there was a decreasing value of each appearance. Factors which was influenced the fish quality is how to cool the fish and the container condition. The fish price that formed in the final consumer is $R p$ 23,019.84 for Frigate tuna and $R p$ 17,019.80 for Goldband goatfish. Factors that influence the price of fish was the cost of raw materials to buy Frigate tuna and Goldband goatfish, labor costs, and overhead costs.

Keywords: transportation condition, quality and the price of fish, Lempasing.

\section{PENDAHULUAN}

Ikan merupakan suatu komoditas bahan pangan yang mudah mengalami kerusakan (perishable food) karena adanya kandungan protein dan air yang cukup tinggi, oleh karena itu diperlukan penanganan untuk mencegah penurunan mutu ikan. Nurjanah et al. (2006) menyatakan bahwa penurunan mutu ikan dapat terjadi karena beberapa hal, yaitu faktor internal yang lebih banyak berkaitan dengan kondisi ikan itu sendiri maupun faktor eksternal yang berkaitan dengan lingkungan dan perlakuan manusia.

Kesegaran ikan merupakan suatu hal yang sangat penting untuk diperhatikan guna menentukan mutu dan harganya. Secara umum, setiap jenis ikan memiliki pola dan kecenderungan yang berbeda setiap spesiesnya dalam hal penurunan mutu ikan. Penurunan mutu tersebut biasanya dipengaruhi oleh beberapa faktor, yaitu jenis dan kondisi biologis ikan, proses kematian, waktu, cara penanganan, dan fasilitas yang digunakan dalam penanganan ikan (Metusalach et al. 2014).

Transportasi adalah suatu komponen penting yang digunakan untuk memindahkan barang atau manusia dari satu tempat ke tempat yang lain sesuai keinginan penggunanya. Bagi sebagian besar manusia, menggunakan transportasi merupakan cara yang sering dilakukan untuk mempermudah dalam melaksanakan aktifitas sehari-hari seperti mendistribusikan ikan hasil tangkapan nelayan dari pelabuhan perikanan ke daerah konsumen. Khusus terhadap pendistribusian ikan hasil tangkapan, diperlukan penanganan yang lebih baik agar kualitas atau mutu ikan tetap terjaga sampai akhir pendistribusian. Hal tersebut masih kurang disadari oleh distributor yang mengangkut ikan dari banyak pelabuhan perikanan ke daerah konsumen. Lubis et al. (2010) menyatakan bahwa, khusus terhadap ikan hasil tangkapan, permasalahan yang masih sering dijumpai di Indonesia adalah penanganan ikan yang kurang baik atau tidak menggunakan rantai dingin selama transportasi dari pelabuhan perikanan sampai ke daerah konsumen. Oleh karena itu, mengetahui terkait sarana transportasi yang digunakan serta penanganan ikan selama proses pendistribusian sangat penting untuk dilakukan.

Pelabuhan Perikanan Pantai (PPP) Lempasing merupakan salah satu dari empat pelabuhan perikanan yang terdapat di Provinsi Lampung. Pelabuhan Perikanan Pantai Lempasing mempunyai peranan yang sangat strategis guna meningkatkan pengembangan usaha di bidang perikanan tangkap. Hal tersebut dikarenakan tingginya jumlah ikan hasil tangkapan yang didaratkan. Berdasarkan hasil pelelangan yang dilakukan di PPP Lempasing, terhitung sejak tahun 2012 sampai dengan 2016, PPP 
Lempasing mampu memproduksi ikan hasil tangkapan rata-rata sebesar $863.796 \mathrm{~kg}$ setiap tahunnya, sedangkan jumlah ikan yang masuk melalui jalur darat dari berbagai daerah berjumlah $3.689 .325 \mathrm{~kg}$ pada tahun 2016. Angka tersebut tentunya sangat potensial untuk mendukung keberlangsungan dalam memenuhi kebutuhan ikan di Provinsi Lampung. Daerah pendistribusian ikan dari PPP Lempasing sangat luas, antara lain Kota Bandar Lampung, Kota Metro, Lampung Tengah, Lampung Barat, Lampung Selatan, dan Tanggamus (Putri, 2014). Namun sejauh ini belum diketahui bagaimana kualitas ikan sesampainya di daerah konsumen melalui sarana transportasi yang digunakan dan penanganan ikan selama pendistribusian. Oleh karena itu penelitian ini untuk mengetahui pengaruh kondisi transportasi terhadap mutu dan harga ikan dari PPP Lempasing ke daerah konsumen penting untuk dilakukan.

Penelitian ini bertujuan untuk mendeskripsikan sarana transportasi yang digunakan dan penanganan ikan selama transportasi oleh pedagang untuk mendistribusikan ikan hasil tangkapan dari PPP Lempasing ke daerah konsumen, menghitung pengaruh mutu ikan selama transportasi dari PPP Lempasing ke daerah konsumen, dan menentukan faktor-faktor yang dapat mempengaruhi mutu ikan selama transportasi dari PPP Lempasing ke darah konsumen, serta mendapatkan besaran harga ikan yang terbentuk di konsumen akhir dan faktor-faktor yang mempengaruhinya. Diharapkan penelitian ini dapat sebagai bahan informasi bagi pedagang dan pengusaha di bidang perikanan terkait ada atau tidaknya pengaruh kondisi transportasi terhadap mutu dan harga ikan dari PPP Lempasing ke daerah konsumen dan sebagai bahan informasi bagi pedagang, pengusaha di bidang perikanan, dan pengelola pelabuhan terhadap faktor-faktor yang mempengaruhi penurunan mutu ikan selama transportasi dari PPP Lempasing ke daerah konsumen.

\section{METODE PENELITIAN}

Penelitian ini dilaksanakan pada bulan Juli 2017 di Pelabuhan Perikanan Pantai Lempasing yang beralamatkan di Jl. RE. Martadinata KM. 6, Desa Lempasing Kecamatan Teluk Betung Provinsi Lampung. Alat dan bahan yang digunakan pada penelitian ini yaitu ikan tongkol (Euthynnus affinis),ikan kuniran (Upeneus moluccensis), kuesioner,alat tulis, laptop, kamera, serta basket untuk meletakkan ikan. Metode penelitian yang digunakan adalah studi kasus terhadap pengaruh kondisi transportasi terhadap mutu dan harga ikan dari Pelabuhan Perikanan Pantai Lempasing ke daerah konsumen. Batasan daerah konsumen yang dipilih dalam penelitian ini adalah Kota Metro yang berjarak 60,4 km dari PPP Lempasing.

Teknik pengambilan sampel pada penelitian ini dilakukan dengan menggunakan teknik purposive sampling, yaitu jumlah sampel yang akan diambil telah ditetapkan sesuai dengan kriteria yang ditentukan yaitu 1 orang distributor yang mendistribusikan ikan dari PPP Lempasing ke daerah konsumen, dan diambil sejumlah 25 ekor ikan tongkol (Euthynnus affinis) dan 25 ekor ikan kuniran (Upeneus moluccensis) untuk dilakukan pengamatan secara organoleptik. Pengambilan jumlah sampel tersebut ditentukan berdasarkan beberapa pertimbangan biaya yang harus dikeluarkan peneliti untuk membeli ikan dan lama waktu yang dibutuhkan untuk menganalisis secara organoleptik pada saat berada di PPP Lempasing. Besaran harga jual ikan dibatasi sampai harga jual ikan yang terbentuk di distributor dan pedagang ikan di Kota Metro.

Prosedur analisis data yang digunakan pada penelitian ini meliputi kondisi sarana transportasi yang digunakan selama pendistribusian ikan hasil tangkapan dari PPP Lempasing ke daerah konsumen dianalisis secara deskriptif kualitatif setelah dilakukan pengamatan di lokasi dan pengaruh mutu ikan selama pendistribusian dari PPP Lempasing ke daerah konsumen dianalisis secara deskriptif kualitatif dan kuantitatif setelah dilakukan penilaian organoleptik, sehingga langkahlangkah yang harus dilakukan untuk menilai mutu dan kualitas ikan adalah sebagai berikut:

1. Melakukan pengukuran secara organoleptik sebanyak 25 ikan tongkol (Euthynnus affinis) dan 25 ekor ikan kuniran (Upeneus moluccensis) sebelum proses pendistribusian berlangsung. 
2. Melakukan observasi pada saat proses pendistribusian berlangsung.

3. Melakukan pengukuran kembali secara organoleptik pada saat sampel ikan telah sampai di Kota Metro.

Selanjutnya, dilakukan analisis uji peringkat bertanda Wilcoxon setelah didapatkan nilai dari organoleptik. Nasoetion dan Barizi (1975) menyatakan bahwa, langkah-langkah yang dilakukan dalam pengujian uji peringkat bertanda wilcoxon adalah:

1. Memberikan peringkat kepada masing-masing beda sesuai dengan besarnya.

2. Memberikan tanda positif atau negatif pada setiap peringkat sesuai dengan tanda dari beda nilai yang dihasilkan.

3. Menjumlahkan peringkat yang memiliki tanda positif atau negatif tergantung darimana yang memberikan nilai terkecil, kemudian lambangkan dengan huruf $\mathrm{T}$.

4. Bandingkan nilai $\mathrm{T}$ yang diperoleh dengan nilai $\mathrm{T} \alpha$.

Adapun rumus yang digunakan untuk memberi pangkat beda yaitu:

Keterangan :

$$
\frac{\sum_{i=1}^{n} n^{*}}{N}
$$

$\mathrm{n}^{*}=$ Peringkat yang sama

$\mathrm{N}$ = Banyak pengamatan yang sama

Faktor-faktor yang mempengaruhi mutu ikan selama transportasi dari PPP Lempasing ke daerah konsumen dianalisis secara deskriptif kualitatif. Parameter yang digunakan untuk mengetahui faktor-faktor penyebab penurunan mutu tersebut antara lain kondisi kebersihan transportasi yang digunakan, lama waktu pendistribusian dan cara pemberian es, kondisi keranjang yang digunakan (jenis keranjang, kebersihan keranjang, dan jenis bahan keranjang), posisi penyusunan keranjang, dan lain-lain.

Besaran harga ikan yang terbentuk di konsumen dan faktor-faktor yang mempengaruhinya dianalisis secara deskriptif kuantitatif setelah dilakukan perhitungan harga pokok produksi. Adapun rumus perhtungan analisis Harga Pokok Produksi (HPP) adalah sebagai berikut:

$$
\begin{array}{ll}
\text { Biaya bahan baku } & =R p . x x x \\
\text { Biaya tenaga kerja langsung } & =R p \cdot x x x \\
\text { Biaya } \text { overhead } & =R p . x x x+ \\
\text { Harga pokok produksi (HPP) } & =\text { Rp. } x x x
\end{array}
$$

$$
\text { Harga pokok persatuan }=\frac{\text { Jumlah harga pokok jenis tertentu }}{\text { Jumlah produk }}
$$

Jumlah harga pokok jenis tertentu $=\left(\frac{\text { Jumlah produk yang akan dijual }}{\text { Jumlah produk keseluruhan }} \times 100 \%\right) \times$ HPP

Harga jual $=$ Harga pokok persatuan + mark up

$$
=\text { Harga pokok persatuan }+(\% \times \text { Harga pokok persatuan })
$$

Keterangan :

- Biaya bahan baku

- Biaya tenaga kerja langsung

- Biaya overhead
: biaya harga bahan baku pembelian ikan dan biaya transportasi.

: gaji pekerja angkut di PPP Lempasing dan gaji pekerja angkut di pasar.

: biaya penyewaan ruko, biaya keamanan dan lingkungan pasar, biaya penggunaan air bersih, biaya pembelian es, dan biaya pembayaran listrik. 


\section{HASIL DAN PEMBAHASAN}

\section{Penanganan Ikan Selama Transportasi dalam Pendistribusian Ikan Hasil Tangkapan dari PPP Lempasing ke Daerah Konsumen}

Penanganan ikan hasil tangkapan yang akan didistribusikan ke daerah konsumen sangatlah penting untuk diperhatikan. Lubis et al. (2010) menyatakan bahwa, proses penanganan merupakan proses yang sangat penting untuk hasil tangkapan ikan segar mulai ikan didaratkan di pelabuhan perikanan sampai selama transportasi pendistribusian menuju hinterland-nya.

Khusus untuk pendistribusian ikan hasil tangkapan yang didistribusikan ke Kota Metro, transportasi yang digunakan berupa mobil pick up dengan ukuran panjang 4,195 meter, lebar 1,655 meter, dan tinggi 1,850 meter serta memiliki kapasitas angkut barang sebesar $820 \mathrm{~kg}$. Setiap harinya, ikan yang didistribusikan oleh distributor ke daerah konsumen di Kota Metro mencapai kurang lebih sebanyak $900 \mathrm{~kg}$ sampai dengan $1.000 \mathrm{~kg}$. Ikan-ikan tersebut diangkut dan disusun sedemikian rupa agar tidak mengalami pergeseran muatan pada saat proses pendistribusian berlangsung. Tata cara pemuatan yang dilakukan oleh distributor pada saat pendistribusian ikan hasil tangkapan dari PPP Lempasing ke daerah konsumen di Kota Metro belum dilakukan secara baik dan benar. Hal tersebut dikarenakan, daya muat pada saat pendistribusian ikan hasil tangkapan ke daerah konsumen melebihi kapasitas muat kendaraan. Ketetapan daya muat maksimum mobil yang digunakan untuk pendistribusian ikan hasil tangkapan yaitu sebesar $820 \mathrm{~kg}$, namun kenyataannya distributor membawa muatan ikan sebesar $900 \mathrm{~kg}$. Hal tersebut tentunya dapat memicu terjadinya berbagai faktor yang dapat membahayakan pengendara seperti, tidak stabilnya laju kendaraan sehingga mengakibatkan kecelakaan, rusaknya komponen kendaraan akibat tidak kuat menahan beban yang terlalu berat, dan lain-lain.

Penanganan ikan yang dilakukan oleh distributor pada saat pendistribusian ikan hasil tangkapan dari PPP Lempasing ke Kota Metro yaitu dengan memasukan ikan ke dalam wadah fiber. Karakteristik wadah yang digunakan oleh distributor untuk mengangkut ikan ke daerah konsumen di Kota Metro antara lain yaitu memiliki ukuran panjang sebesar $80 \mathrm{~cm}$, lebar $60 \mathrm{~cm}$, dan tinggi $70 \mathrm{~cm}$. Kondisi wadah yang digunakan juga memiliki penutup pada bagian atasnya, sehingga ikan yang diletakan di dalam wadah fiber tersebut terhindar dari asap, debu, dan berbagai jenis gangguan yang dapat menyebabkan mutu ikan menjadi cepat menurun. Salah satu usaha yang dilakukan distributor untuk menjaga agar kondisi mobil tetap bersih pada saat proses pengangkutan dan pembongkaran adalah dengan menambahkan alas berupa karpet yang terbuat dari karet pada bak mobil pick up agar kondisi bak menjadi rata dan memudahkan para pekerja untuk membersihkannya apabila terdapat ikan-ikan yang terjatuh atau air yang menggenang. Parkinson dalam Granata (2012:297) menyatakan bahwa kondisi kebersihan dan sanitasi dalam penanganan makanan laut berdasarkan konsepsi Hazard Analysis Critical Control Point (HACCP) pada ikan dan hasil ikan yaitu semua wadah yang digunakan untuk pendistribusian ikan atau produk hasil perikanan harus bersih pada setiap permukaan, semua bahan kemasan, karyawan, dan keseluruhan lingkungan yang digunakan untuk proses pengolahan dan pendistribusian ikan.

\section{Pengaruh Mutu Ikan Selama Transportasi dari PPP Lempasing ke Daerah Konsumen}

Ikan hasil tangkapan membutuhkan suatu penanganan agar mutu tetap terjaga. Penanganan ikan selama pendistribusian dimulai dari proses pengangkutan sampai dengan pembongkaran sering tidak dilakukan dengan baik, sehingga ikan sering sekali mengalami penurunan mutu. Penanganan ikan oleh distributor pada saat dikirimkan dari PPP Lempasing ke Kota Metro dilakukan dengan sangat teliti. Ikan-ikan tersebut disimpan dalam wadah yang telah diberikan es dan masing-masing wadah tersebut disesuaikan dengan jenis ikannya. Berdasarkan pengamatan yang dilakukan pada saat ikan berada di PPP Lempasing dan setelah ikan berada di Kota Metro, masing-masing ikan mempunyai nilai yang bervariatif pada setiap sampel yang diuji. Nilai-nilai tersebut disajikan dalam diagram dibawah ini: 


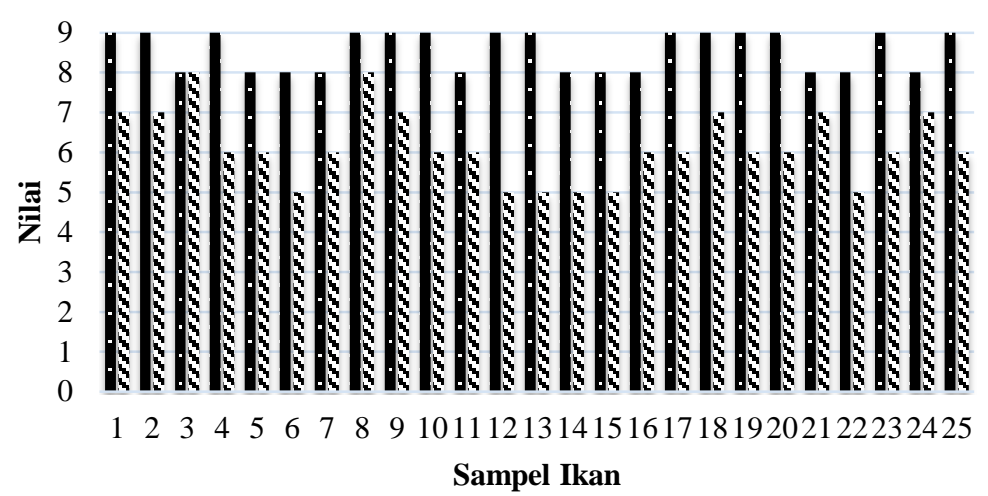

- SEBELUM $\times$ SESUDAH

Gambar 1. Hasil Penilaian organoleptik insang ikan tongkol

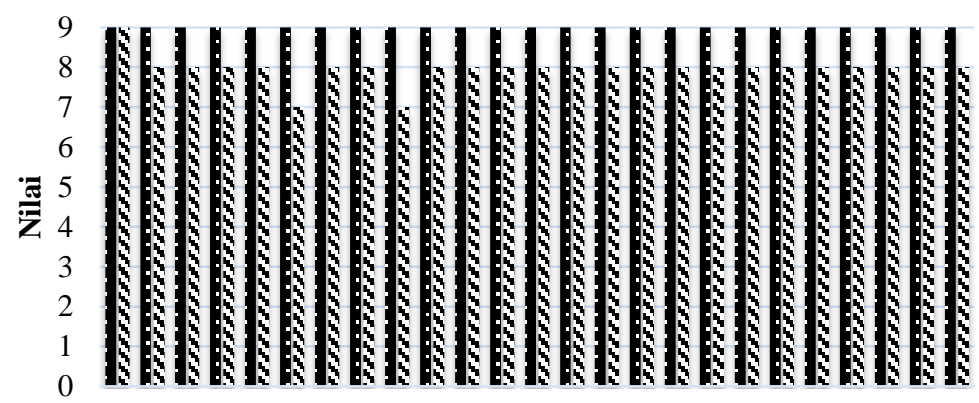

12234456788910111213141516171819202122232425

Sampel Ikan

a SEBELUM × SESUDAH

Gambar 2. Hasil penilaian organoleptik mata ikan ikan tongkol

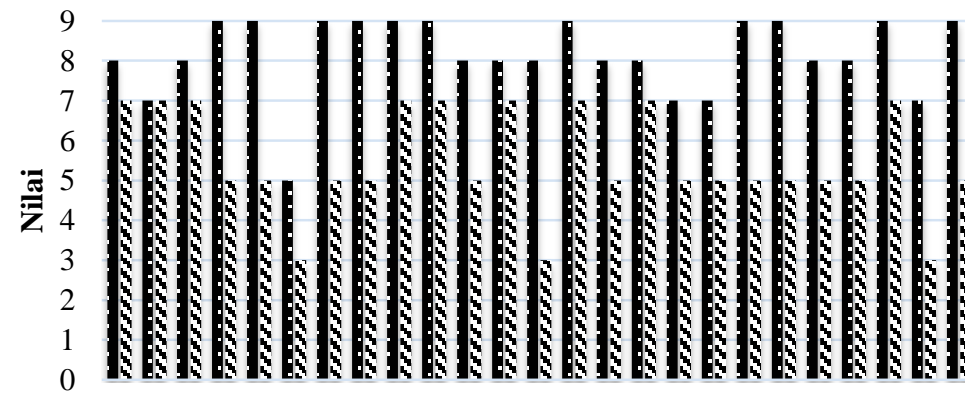

12234456788910111213141516171819202122232425

Sampel Ikan

m SEBELUM $\mathbf{s}$ SESUDAH

Gambar 3. Hasil penilaian organoleptik penekanan otot ikan tongkol

Berdasarkan grafik di atas, terjadi penuruan nilai pada ikan tongkol (Euthynnus affinis) setelah dilakukannya distribusi ikan hasil tangkapan dari PPP Lempasing ke Kota Metro. Hasil pengamatan menunjukkan bahwa terdapat 24 sampel ikan yang mengalami penuruan nilai pada kenampakan di bagian insang, dan sebanyak 1 sampel ikan memiliki nilai tetap (Gambar 1). Penurunan nilai tersebut juga dialami pada kenampakan mata dan penekanan otot. Sebanyak 24 sampel ikan tongkol 
mengalami penurunan nilai pada kenampakan mata, dan 1 sampel ikan memiliki nilai yang tetap (Gambar 2). Selain itu, kenampakan pada bagian otot ikan tongkol mengalami penurunan nilai sebanyak 24 sampel, dan 1 sampel memiliki nilai yang tetap (Gambar 3). Penurunan nilai tersebut juga diperkuat dengan adanya hasil dari uji peringkat bertanda wilcoxon dimana nilai-p pada insang, mata dan penekanan otot ikan tongkol berturut-turut yaitu 0,00 yang artinya kurang dari taraf nyata 5\%. Maka hasil tersebut menolak hipotesis nol atau nilai yang dimiliki insang, mata, dan penekanan otot pada ikan tongkol sebelum proses pendistribusian berlangsung lebih baik daripada setelah ikan didistribusikan.

Khusus untuk ikan kuniran, perbandingan nilai pada saat ikan berada di PPP Lempasing dan setelah ikan berada di Kota Metro masing-masing kenampakan memiliki nilai sebagai berikut:

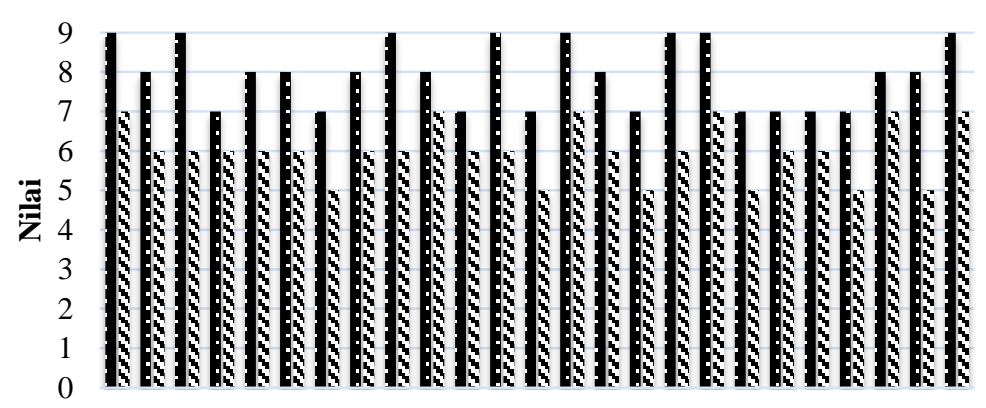

$122345 \quad 6789910111213141516191819202122232425$

Sampel Ikan

m SEBELUM $\mathbf{x}$ SESUDAH

Gambar 4. hasil penilaian organoleptik insang ikan kuniran

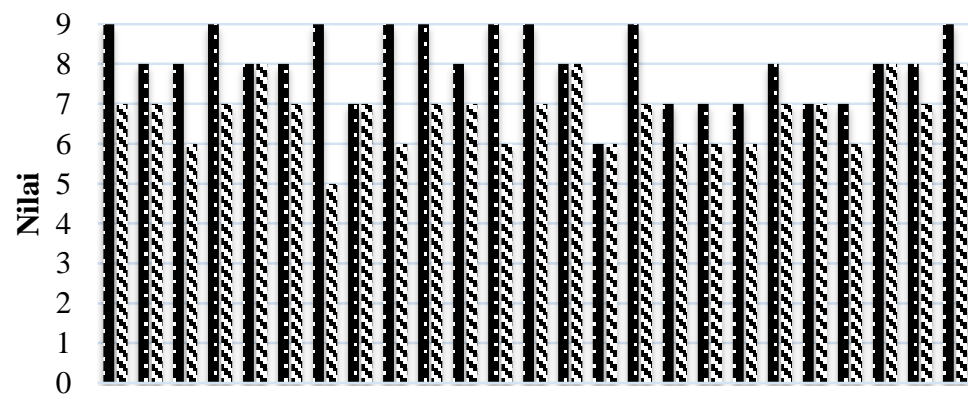

12334566789910111213141516171819202122232425

Sampel Ikan

- SEBELUM $\sim$ SESUDAH

Gambar 5. Hasil penilaian organoleptik mata ikan kuniran 


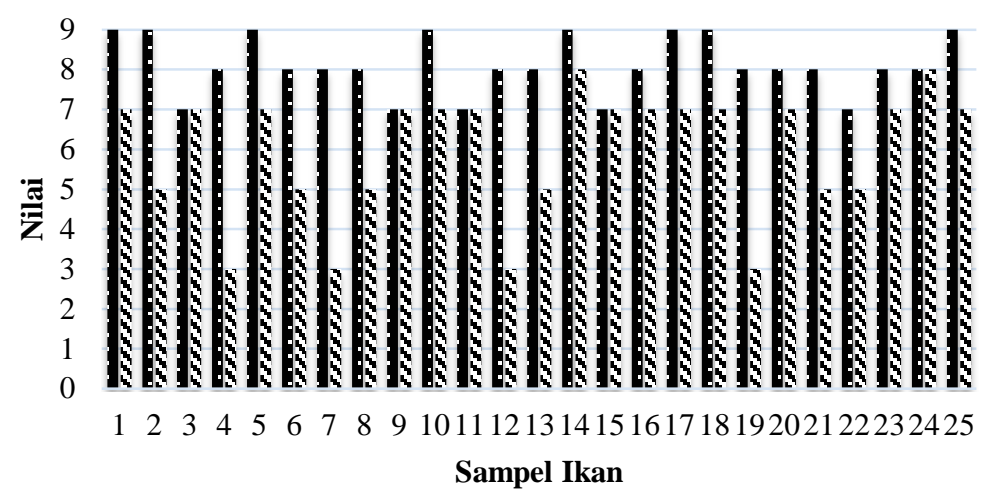

m SEBELUM $\mathbf{x}$ SESUDAH

Gambar 6. Hasil penilaian organoleptik penekanan otot ikan kuniran

Grafik di atas menunjukkan bahwa uji organoleptik yang dilakukan untuk menilai 25 sampel ikan kuniran (Upeneus moluccensis) yaitu, terjadi penurunan nilai dari 25 sampel ikan kuniran yang diukur berdasarkan kenampakan insang setelah dilakukan pendistribusian dari PPP Lempasing ke daerah konsumen di Kota Metro (Gambar 4). Selain itu, pada kenampakan mata terjadi penurunan nilai pada 19 sampel ikan yang didistribusikan dan 6 sampel lainnya memiliki nilai yang tetap (Gambar 5). Penurunan nilai tersebut juga terjadi pada 20 sampel ikan yang diukur berdasarkan penekanan otot dan 5 sampel yang lainnya memiliki nilai yang tetap (Gambar 6). Penurunan nilai tersebut juga diperkuat dengan adanya hasil dari uji peringkat bertanda wilcoxon dimana masingmasing kenampakan (insang, mata, dan penekanan otot) memiliki nilai-p sebesar 0,00 atau kurang dari taraf nyata 5\%. Maka hasil tersebut menolak hipotesis nol atau nilai ikan berdasarkan pengamatan insang, mata, dan penekanan otot pada ikan kuniran sebelum proses pendistribusian berlangsung, lebih baik daripada nilai yang dihasilkan setelah ikan didistribusikan.

\section{Faktor-faktor yang Mempengaruhi Mutu Ikan Selama Transportasi dari PPP Lempasing ke Daerah Konsumen}

Hasil analisis yang dilakukan untuk mengetahui adanya penurunan mutu pada saat pendistribusian ikan dari PPP Lempasing menuju Kota Metro yaitu dengan mengamati kebersihan transportasi yang digunakan untuk pendistribusian, lama waktu pendistribusian dan cara pemberian es, kondisi keranjang yang digunakan (jenis keranjang, kebersihan keranjang, dan jenis bahan dari keranjang), serta penyusunan keranjang. Faktor yang paling berpengaruh terhadap penurunan mutu pada saat pendistribusian ikan hasil tangkapan dari PPP Lempasing menuju Kota Metro yaitu cara penanganan ikan yang kurang baik di atas mobil khususnya pada pemberian es dan kondisi wadah yang digunakan. Es yang digunakan oleh distributor untuk mempertahankan mutu ikan berupa es balok. Es tersebut didapatkan dari salah satu perusahaan es yang terdapat di PPP Lempasing. Pemberian es pada setiap wadah dilakukan dengan cara memecahkan es menjadi bongkahanbongkahan dan diletakkan di dasar dan atas ikan. Pemberian es yang tidak dilakukan dengan cara yang benar mengakibatkan es yang dibawa pada saat pendistribusian lebih cepat meleleh. Akibatnya, wadah yang digunakan untuk membawa ikan tergenang oleh lelehan es yang bercampur dengan lendir dan darah yang keluar dari tubuh ikan. James dan James (2014) menyatakan bahwa, ikan yang disimpan dalam lapisan atau tumpukan es memiliki panas tubuh yang mampu membuat es meleleh. Oleh karena itu, perbandingan yang digunakan untuk menyimpan ikan dalam ruang dingin harus diperhatikan agar es yang digunakan untuk menyimpan ikan tidak cepat meleleh.

Selain cara pemberian es yang kurang baik, wadah yang digunakan pada saat pendistribusian juga mempengaruhi penurunan mutu ikan. Adanya lelehan es yang bercampur dengan darah dan lendir yang terdapat di dalam wadah mengakibatkan proses perkembangbiakan mikroorganisme 
menjadi semakin cepat. Ilyas (1993) menyatakan bahwa, wadah atau karoseri alat angkut harus mampu mempertahankan suhu produk sesuai ketentuan; tidak diterobos oleh panas dari luar wadah; tidak dicemari oleh air, gas, udara, kotoran dan lain-lain yang dapat mengganggu kesehatan produk; dan mampu untuk mengangkut produk. Konstruksi wadah yang digunakan untuk proses pendistribusian ikan hasil tangkapan dari PPP Lempasing menuju Kota Metro telah menggunakan bahan yang kokoh. Seluruh sisi dari wadah memiliki konduktivitas termal yang baik yaitu tahan terhadap rembesan air, ringan, dan tahan terhadap goncangan. Namun, pada setiap wadah yang digunakan tidak terdapat saluran pembuangan, sehingga lendir, kotoran, dan darah dapat terkontaminasi dengan ikan.

\section{Besaran Harga yang Terbentuk di Konsumen Akhir dan Faktor-faktor yang Mempengaruhinya}

Berdasarkan unsur-unsur biaya yang harus dikeluarkan, distributor menetapkan harga pokok produk secara full costing. Perhitungan harga pokok produk didapatkan dengan mengakumulasikan biaya-biaya yang dikeluarkan selama pendsitribusian ikan berlangsung.berikut adalah perhitungan Harga Pokok Produksi dari ikan tongkol dan ikan kuniran:

1. Tongkol

a. Harga pokok produksi ikan tongkol

- Harga pokok produksi= biaya bahan baku+biaya tenaga kerja+biaya overhead

- Biaya bahan baku= biaya pembelian ikan+biaya angkut

- $\quad$ Biaya bahan baku ikan tongkol = Rp.3.960.000+ Rp.49.800

- $\quad$ Biaya bahan baku ikan tongkol = Rp. 4.009 .800

- $\quad$ Hpp tongkol = biaya bahan baku+biaya tenaga kerja+biaya overhead

- $\quad$ Hpp tongkol = Rp.4.009.800+ Rp.157.473,68+Rp.53.031,58

- $\quad$ Hpp tongkol $=$ Rp.4.220.305,26

b. Hargapokok persatuan ikan tongkol

- Hp persatuan ikan tongkol= $\frac{\text { Harga pokok produksi ikan tongkol }}{\text { Banyaknya volume ikan }}$

- Hp persatuan ikan tongkol $=\frac{\text { Rp.4.220.305,26 }}{220 \mathrm{~kg}}$

- $\quad$ Hp persatuan ikan tongkol= Rp.19.183,20/kg

c. Harga jual ikan tongkol

- Harga jual ikan tongkol= harga pokok persatuan + mark up

- Harga jual ikan tongkol= harga pokok persatuan $+(\% \times$ harga pokok persatuan $)$

- $\quad$ Harga jual ikan tongkol= Rp. $19.183,20 / \mathrm{kg}+(20 \% \times \mathrm{Rp} .19 .183,20 / \mathrm{kg})$

- $\quad$ Harga jual ikan tongkol= Rp.19.183,20/kg+Rp.3.836,64/kg

- $\quad$ Harga jual ikan tongkol= Rp.23.019,84/kg

2. Kuniran

a. Harga pokok produksi ikan kuniran

- $\quad$ Biaya bahan baku ikan kuniran = Rp.7.800.000+ Rp.135.800

- $\quad$ Biaya bahan baku ikan kuniran = Rp.7.935.800

- Hpp kuniran = biaya bahan baku+biaya tenaga kerja+biaya overhead

- $\quad$ Hpp kuniran = Rp.7.935.800+Rp.429.473,68+Rp.144.631,58

- $\quad$ Hpp kuniran = Rp.8.509.905,26

b. Harga pokok persatuan ikan kuniran

- $\quad$ Hp persatuan ikan kuniran $=\frac{\text { harga pokok produksi ikan kuniran }}{\text { banyaknya volume ikan }}$

- $\quad$ Hp persatuan ikan kuniran = "Rp.8.509.905,26" /"600 kg"

- $\quad$ Hp persatuan ikan kuniran $=$ Rp.14.183,17/kg

c. Harga jual ikan kuniran

- Harga jual ikan kuniran= harga pokok persatuan+mark up

- Harga jual ikan kuniran= harga pokok persatuan $+(\% \times$ harga pokok persatuan $)$ 
- $\quad$ Harga jual ikan kuniran= Rp.14.183,17/kg+ $(20 \% \times$ Rp. $14.183,17 / \mathrm{kg})$

- $\quad$ Harga jual ikan kuniran= Rp.17.019,80/kg

Faktor yang paling berpengaruh dalam pembentukan harga jual ikan hasil tangkapan dari PPP Lempasing menuju Kota Metro yaitu biaya untuk pembelian bahan baku ikan yang terdiri dari pembelian ikan tongkol sebesar Rp.4.009.800, ikan kuniran sebesar Rp.7.935.800, biaya tenaga kerja ikan tongkol dan ikan kuniran sebesar Rp.157.473,68 dan Rp.429.473,68, dan yang terakhir yaitu biaya overhead. Biaya tersebut masing-masing sebesar Rp.53.031,58 untuk ikan tongkol, dan Rp.144.631,58 untuk ikan kuniran.

Besaran harga ikan tongkol dan ikan kuniran yang terbentuk dari proses pendistribusian dari PPP Lempasing menuju Kota Metro yaitu sebesar Rp.23.019,84/kg dan Rp.17.019,80/kg. Besaran harga tersebut terbentuk berdasarkan biaya-biaya yang harus dikeluarkan oleh distributor untuk memenuhi kebutuhan selama proses pendistribusian berlangsung. Harga pokok produksi yang terbentuk dari kedua jenis ikan tersebut antara lain yaitu Rp.4.220.305,26 dan Rp.8.509.905,26, sedangkan harga pokok persatuan yang terbentuk sebesar Rp.19.183.20/kg dan Rp.14.183,17/kg. Keuntungan yang diperoleh distributor setelah pendistribusian ikan hasil tangkapan dari PPP Lempasing menuju Kota Metro yaitu Rp.3836,64/kg untuk ikan tongkol dan Rp.2836.63/kg untuk ikan kuniran.

\section{KESIMPULAN DAN SARAN}

\section{Kesimpulan}

1. Jenis transportasi yang digunakan oleh distributor untuk mendistribusikan ikan yaitu berupa mobil pick up dengan ukuran panjang 4,195 meter, lebar 1,655 meter, dan tinggi 1,850 meter serta memiliki kapasitas angkut barang sebesar $820 \mathrm{~kg}$. Selain itu, mobil juga tidak dilengkapi dengan pendingin dan atap pada bagian atasnya. Penanganan yang dilakukan oleh distributor selama pendistribusian berlangsung yaitu dengan memasukkan ikan ke dalam wadah fiber dengan ukuran panjang sebesar $80 \mathrm{~cm}$, lebar $60 \mathrm{~cm}$, dan tinggi $70 \mathrm{~cm}$ dengan kapasitas angkut sebesar $100 \mathrm{~kg}$.

2. Berdasarkan penilaian organoleptik yang telah dilakukan, terjadi penurunan mutu pada ikan tongkol dan ikan kuniran. Penurunan mutu tersebut dibuktikan dengan hasil uji peringkat bertanda wilcoxon. Hasil tersebut antara lain nilai-p pada insang, mata dan penekanan otot ikan tongkol berturut-turut yaitu sebesar 0,00 yang artinya kurang dari taraf nyata 5\% dan nilai masing-masing kenampakan (insang, mata, dan penekanan otot) pada ikan kuniran memiliki nilai-p sebesar 0,00 atau kurang dari taraf nyata 5\%. Nilai tersebut menolak hipotesis nol atau terima hipotesis satu, yang berarti terdapat pengaruh perbedaan terhadap perlakuan.

3. Faktor-faktor yang mempengaruhi adanya penurunan mutu ikan yang terjadi selama pendistribusian berlangsung dari PPP Lempasing ke daerah konsumen di Kota Metro adalah tidak diberlakukannya sistem pemberian es yang sesuai yaitu es tidak diberikan pada setiap tumpukan dan di atas tumpukan terakhir sehingga sebaran suhu yang diakibatkan dari pemberian es tidak terdistribusi secara merata. Wadah yang digunakan tidak memiliki saluran pembuangan air, sehingga apabila es yang terdapat di dalam wadah tersebut meleleh, maka darah, lendir dan air lelehan es menggenangi ikan yang ada didalamnya.

4. Besaran harga ikan yang terbentuk ketika sampai di tangan konsumen yaitu Rp. 23.019,84 untuk ikan tongkol dan Rp.17.019,80 untuk ikan kuniran. Keuntungan yang diperoleh distributor setelah pendistribusian ikan hasil tangkapan dari PPP Lempasing menuju Kota Metro yaitu sebesar Rp.3.836,64/kg untuk ikan tongkol dan Rp.2.836.63/kg untuk ikan kuniran. Faktorfaktor yang mempengaruhi terhadap pembentukan harga ikan tongkol dan ikan kuniran di daerah konsumen di Kota Metro yaitu adanya biaya bahan baku pembelian ikan tongkol dan ikan kuniran, biaya tenaga kerja yang terdiri dari kuli angkut dan kuli troli di PPP Lempasing, kuli 
angkut dan kuli troli di pasar, dan 2 orang kuli tetap di pasar, kemudian biaya overhead yang terdiri dari biaya penyewaan ruko, biaya keamanan, biaya kebersihan, biaya sampah, biaya pembelian es, biaya pembayaran listrik, biaya plastik, dan biaya pembelian pulsa.

\section{Saran}

Perlu adanya suatu pelatihan yang diberikan kepada seluruh nelayan maupun pedagang yang terdapat di Pelabuhan Perikanan Pantai Lempasing dan di Kota Metro terkait proses penanganan ikan yang sesuai dengan prosedur HACCP agar mutu yang dihasilkan tetap dalam kondisi tetap segar. Selain itu, perlu adanya penelitian lanjutan terkait pengaruh berbagai jenis kondisi transportasi yang digunakan untuk pendistribusian ikan hasil tangkapan dari pelabuhan perikanan menuju hinterlandnya.

\section{DAFTAR PUSTAKA}

Ilyas S. 1993. Teknologi Refrigerasi Hasil Perikanan Jilid II Teknik Pembekuan Ikan.Jakarta (ID): Paripurna

James S J, James C. 2014. Food Safety Management. North East Lincolnshire (GB): Elsevier.Inc Chapter 20

Lubis E, Wiyono E S, Nirmalanti M. 2010. Penanganan Selama Transportasi Terhadap Hasil Tangkapan Didaratkan di Pelabuhan Perikanan Nizam Zachman: Aspek Biologi dan Teknis. Jurnal Mangrove dan Pesisir X (1). 02 (2010): 1-7

Metusalach, Kasmiati, Fahrul, Jaya I. 2014. Pengaruh Cara Penangkapan, Fasilitas Penanganan dan Cara Penanganan Ikan Terhadap Kualitas Ikan yang Dihasilkan. Jurnal IPTEKS PSP, Vol.1 (1) 04 (2014): 40-52

Nurjanah, Nurhayati T, Zakaria R. 2011. Kemunduran Ikan Gurami (Osphronemus gourami) Pasca Kematian pada Penyimpanan Suhu Chilling. AKUATIK-Jurnal Sumberdaya Perairan, Vol.5 No. 2 Tahun 2011

Parkinson N G.[tahun tidak diketahui]. Cleaning and Sanitation [Editorial]. Granata A, Flick G J, Martin E. 2012. The Seafood Industry Species, Product, Processing, and Safety.United Kingdom (GB): Willey-Blackwell

Putri A S. 2014. Distribusi Hasil Tangkapan di Pelabuhan Perikanan Pantai Lempasing Bandar Lampung [skripsi]. Bogor (ID): Institut Pertanian Bogor. 